\title{
Perlindungan Hukum Ekspresi Kreatif Manusia: Telaah Terhadap Perlindungan Hak Kekayaan Intelektual Dan Ekspresi Budaya Tradisional
}

\author{
Oleh: M Zulfa Aulia \\ Mahasiswa Pascasarjana Undip semarang \\ e-mail:
}

\begin{abstract}
The discourse on the protection of the intellectual property rights (HKI) and the expression of traditional culture, is actually a discourse on the legal protection towards the expression of human's creativity. Both of the intellectual property rights (HKI) and the expression of traditional culture are a form of the expression of human's creativity, with only the difference between them is in the novelty. It is understood therefore, that there is dialectical relation between them on the legal protection towards the expression of human's creativity. In such dialectical relation, the legal protection should also be addressed to the traditional culture, not merely on nowadays human creativity.
\end{abstract}

Keyword: Perlindungan hukum, Ekspresi kreatif

\section{Pendahuluan}

Studi tentang perlindungan hukum ekspresi kreatif manusia menjadi menarik dan karenanya perlu dilakukan, setidaknya didasari oleh tiga alasan, yaitu (1) adanya penyalahgunaan ekspresi budaya tradisional yang (di antaranya malah) menggunakan sistem hukum hak kekayaan intelektual (HKI), (2) terikatnya negara-negara untuk menerapkan sistem perlindungan HKI, dan (3) masih buruknya sistem perlindungan ekspresi budaya tradisional.

Pertama, mengenai penyalahgunaan pemanfaatan ekspresi budaya tradisional, maka dapat dikatakan jika dalam beberapa tahun terkahir fenomena ini semakin banyak terjadi. Satu tahun terakhir ini saja misalnya, paling tidak telah terjadi penyerobotan pihak asing terhadap ekspresi 
budaya tradisional dari Indonesia berupa lagu Rasa Sayange, kesenian Barongan, ${ }^{1}$ dan desain ukiran Jepara. ${ }^{2}$ Kasus klaim Rasa Sayange dan Barongan bahkan sempat 'memanaskan' hubungan bilateral Indonesia dengan Malaysia--sebagai negara yang warganya mengklaim dua kesenian ini, ${ }^{3}$ sementara pada kasus ukiran Jepara menjadi tidak wajar dikarenakan diperebutkan oleh dua perusahaan ekspor mebel dari Inggris dan Belanda, yang keduanya sebenarnya sama-sama berproduksi di Indonesia.

Pada kebanyakan kasus, klaim pihak asing terhadap suatu ekspresi budaya tradisional itu tidaklah berhenti pada klaim kepemilikan semata, tetapi juga pada klaim HKI. Pihak-pihak yang mengklaim kepemilikan tersebut berhasrat pula memiliki monopoli penggunaan suatu ekspresi budaya tradisional yang diklaimnya, dalam hal ini hanya sistem hukum HKI yang memungkinkannya. Ini berarti, ketika instrumen hukum HKI yang digunakan itu mengakui suatu karya (ekspresi budaya tradisional) sebagai karya HKI maka berlakulah di sana prinsip eksklusifitas HKI, bahwa hak penggunaan suatu karya hanya ada pada pemilik atau pemegang hak, sedangkan pihak lain--dalam konteks ini termasuk "si korban"--baru dapat menggunakannya juga setelah mendapat izin terlebih dulu dari pemilik haknya.

Kedua, negara-negara di dunia saat ini terikat untuk memberlakukan sistem perlindungan HKI. Meskipun keikutsertaan dan keterikatan sebagian besar negara ini sebenarnya lebih dikarenakan faktor keterpaksaan, ${ }^{4}$ namun dengan telah disepakati dan diratifikasinya perjanjian

${ }^{1}$ Permasalahan ini ramai diberitakan oleh media massa di Indonesia dalam bulan November 2007. Untuk menyebut satu di antaranya adalah: Koran Tempo. “Kasus Klaim Reog, Ponorogo Tempuh Jalur Hukum", 23 November 2007.

${ }^{2}$ Metro TV. "Metro Realita", 19 Maret 2008, 22.35-23.00 WIB.

${ }^{3}$ Dalam sebuah esai kebudayaannya, Mohamad Sobary bahkan menyebut tindakan Malaysia semacam ini sebagai perilaku "si Anak Durhaka", dan sebagai anak durhaka, seperti halnya si Malin Kundang, maka ia layak dan terancam mengalami tragedi kutukan. Lihat: Mohamad Sobary. 2007. “Tragedi Si Anak Durhaka", Kompas, 28 November.

${ }^{4}$ Keterpaksaan ini dapat dilihat dengan diterimanya pemberlakuan rezim HKI oleh negara-negara berkembang (developing countries) untuk menarik investasi asing guna memaksimalkan pemanfaatan sumber daya alam (SDA) yang dimilikinya. Menurut A. Zen Umar Purba, mantan Direktur Jenderal HKI Departemen Hukum dan HAM RI, hal ini terjadi karena tidak samanya garis permulaan (start) antara negara maju dan negara berkembang dalam berkreasi teknologi, yang salah satunya disebabkan oleh tingkat kemampuan yang dihasilkan oleh pendidikan di negara berkembang sangat rendah. Namun, hal itu bukan karena kesalahan mereka semata, tetapi juga karena faktor jajahan negara maju selama berabad-abad, sehingga wajar 
internasional di bidang HKI yang tertuang dalam Trade Related Aspects of Intellectual Property Rights (TRIPs) oleh negara-negara di dunia, ${ }^{5}$ maka-suka atau tidak--sistem HKI telah diakui untuk menjadi bagian dari norma berperilaku dalam suatu hubungan (perdagangan) internasional. Oleh karena faktor keberlakuannya yang demikian ini, sehingga pembahasan perlindungan HKI menjadi perlu diikutkan dalam setiap kali membincangkan perlindungan ekspresi kreatif manusia.

Ketiga, masih lemah dan buruknya perlindungan hukum ekspresi budaya tradisional. Hal ini antara lain ditunjukkan dengan kenyataan adanya klaim kepemilikan terhadap beberapa ekspresi budaya tradisional dan mengambangnya penyelesaian klaim tersebut yang bahkan pada sebagiannya tampak kesulitan dalam membuktikan kepemilikannya. Karena itu, mengupayakan perbaikan perlindungan pada ekspresi budaya tradisional sehingga dapat mengejar kemapanan sistem perlindungan HKI, menjadi mendesak sekarang ini.

tulisan ini akan membahas dialektika dalam perlindungan hukum ekspresi kreatif manusia, baik terhadap ekspresi yang baru (baca: HKI) maupun ekspresi yang lama (yaitu ekspresi budaya tradisional). ${ }^{6}$ Oleh karena secara sepintas telah dikatakan tadi masih buruknya perlindungan hukum pada ekspresi budaya tradisional, maka pada bagian akhir tulisan secara khusus akan dibahas upaya-upaya yang seharusnya perlu segera dilakukan dalam melindunginya.

jika negara-negara berkembang mengalami ketertinggalan, terutama dalam berkreasi di bidang teknologi, karena mereka memang 'pemain baru'. Lihat: A. Zen Umar Purba, "TRIPs dan Negara-negara Berkembang," Jurnal Hukum Internasional, Vol. 1 No. 2 Januari, Jakarta: Lembaga Pengkajian Hukum Internasional FH UI, 2004, Hlm. 256-260.

${ }^{5}$ Saat ini TRIPs telah diratifikasi oleh sebanyak 183 negara, yang selengkapnya dapat dilihat di buku: Tamotsu Hozumi, ASIAN Copyright Handbook. Jakarta: ACCU dan Ikapi, 2006, Hlm. 65-85.

${ }^{6}$ Dalam bahasan semacam ini ekspresi budaya tradisional dipandang sebagai bagian dari ekspresi kreatif manusia. Hal ini didasarkan pada alasan, bahwa budaya, atau kebudayaan, merupakan endapan dari kegiatan dan karya manusia (C. A. van Peursen. 1988. Strategi Kebudayaan. [Edisi kedua]. Yogyakarta: Penerbit Kanisius. Hlm. 9), sehingga jelas ekspresi budaya juga merupakan hasil ekspresi kreatif manusia. 


\section{HKI Dan Hasil Kreatifitas Intelektual Manusia}

HKI secara umum dapat dipahami sebagai hak seseorang untuk menggunakan karya kreatif yang telah dihasilkannya, baik itu karya berupa buku, lagu, merek, tampilan (desain) suatu produk, maupun juga penemuan. Hak menggunakan karya tersebut meliputi kegiatan produksi dan juga komersialisasinya.

Pada perkembangannya, hak menggunakan karya yang terbatas pada pencipta atau penemunya ini lazim disebut dengan hak eksklusif. Dengan hak eksklusif, maka penggunaan suatu karya oleh pihak lain menjadi tertutup, terkecuali penggunaan tersebut masih dalam kepentingan pendidikan, penelitian, dan tidak komersil. Sedangkan penggunaannya dalam wilayah komersiil baru diperbolehkan setelah mendapatkan izin terlebih dulu dari pemilik haknya.

Secara teoretis, diberikannya hak eksklusif kepada pencipta atau penemu suatu karya dimaksudkan sebagai bentuk penghargaan (reward) atas pengorbanan pencipta dan penemunya dalam menghasilkan karya tersebut. ${ }^{7}$ Di sini, lahirnya suatu karya dikonsepsikan telah melalui pengorbanan dari pencipta dan penemunya, baik berkaitan dengan pemikiran, tenaga, waktu, dan secara materi juga uang. Karena adanya pengorbanan dari pencipta dan penemunya ini sehingga dipandang perlu untuk menghormatinya, dalam hal ini penghormatan diberikan dalam bentuk hak eksklusif dalam penggunaannya.

Secara kategoris hasil kreatifitas intelektual pada HKI biasanya dibedakan ke dalam hak cipta dan hak milik perindustrian. Jika hak cipta mencakupi karya di bidang ilmu pengetahuan, seni dan sastra, maka hak milik perindustrian melingkupi karya-karya yang masih dibedakan lagi ke dalam paten, merek, desain industri, desain tata letak sirkuit terpadu (DTLST), indikasi geografis, rahasia dagang, dan perlindungan varietas tanaman (PVT). Hasil kreatifitas yang termasuk ke dalam paten adalah penemuan di bidang teknologi (invensi), pada merek berupa tanda dalam kegiatan perdagangan dan jasa (dan karenanya dikenal merek dagang dan merek jasa), pada desain industri berupa kreasi atau tampilan suatu produk, pada DTLST berupa kreasi dalam sebuah bahan semikonduktor

${ }^{7}$ Robert M. Sherwood, Intellectual Property and Economic Development. Virginia: Alexandria, 1990, Hlm. 37. Lihat juga: Bambang Kesowo, “UU Paten; Latar Belakang dan Prinsip-Prinsip Pokok", dalam Paten, Pemahaman dan Pelaksanaan. Tanpa kota: Pusat Pengkajian Hukum, 1993, Hlm. 31. 
yang menghasilkan fungsi elektronik, pada indikasi geografis berupa tanda nama daerah di suatu produk yang menunjukkan kualitas produk tersebut yang disebabkan oleh faktor geografis, pada rahasia dagang berupa informasi di bidang teknologi yang dijaga kerahasiaannya, dan pada PVT berupa penemuan varietas tanaman.

Meskipun bidang HKI masih terbagi ke dalam hak cipta dan juga hak milik perindustrian, namun kriteria secara umum yang harus dipenuhi agar suatu karya dapat disebut karya HKI adalah telah berwujudnya suatu karya tersebut dan adanya kebaruan di sana. Hal ini berarti, suatu kreatifitas intelektual yang betapapun bagusnya tetapi masih dalam tataran ide, gagasan, konsep, dan belum dituangkan ke dalam suatu karya, maka ia tidaklah dapat disebut sebagai karya HKI. Demikian pula jika karya tersebut telah lama keberadaannya, juga termasuk sebagai bentuk kreatifitas intelektual yang bukan karya HKI.

\section{HKI Dan Ekspresi Budaya Tradisional}

Terdapat beragam macam bahasa yang biasa digunakan untuk menyebut hasil kegiatan intelektual manusia di suatu masyarakat yang dimiliki secara komunal dan telah berlangsung dalam kurun waktu yang lama, di antaranya adalah pengetahuan tradisional, budaya tradisional, dan ekspresi budaya tradisional. Untuk kepentingan metodologis, tulisan ini menggunakan bahasa ekspresi budaya tradisional, dengan pertimbangan, pertama, definisi budaya merujuk pada kebudayaan, yang berarti endapan dari kegiatan dan karya manusia. ${ }^{8}$ Kedua, definisi ekspresi merujuk pada hasil kebudayaan yang terekspresikan ke dalam suatu karya dan dapat ditangkap oleh indera manusia. ${ }^{9}$ ketiga, tradisional, ditujukan

${ }^{8}$ Lihat kembali penjelasan ini dalam catatan kaki no. 6.

${ }^{9}$ Pembatasan istilah budaya melalui ekspresi ini penting, dikarenakan wujud kebudayaan itu sendiri, sebagaimana dijelaskan Koentjaraningrat, paling sedikit terdiri dari tiga, yaitu (1) suatu kompleks dari ide-ide, gagasan-gagasan, nilai-nilai, norma-norma, peraturan dan sebagainya, (2) suatu kompleks aktivitas kelakuan berpola dari manusia dalam masyarakat (disebut juga sistem sosial), dan (3) bendabenda hasil karya manusia (kebudayaan fisik). Wujud kebudayaan yang kedua dan ketiga merupakan wujud kebudayaan yang bersifat konkrit, bisa dilihat, diobservasi, difoto, dan didokumentasikan. (Lihat Koentjaraningrat, Kebudayaan, Mentalitas dan Pembangunan, [Cetakan keduapuluh satu]. Jakarta: Penerbit PT. Gramedia Pustaka Utama, 2004, Hlm. 5-8). Di antara wujud-wujud tersebut, maka pengertian ekspresi dalam tulisan ini merujuk pada wujud kebudayaan yang berupa 
untuk menyatakan bahwa ekspresi budaya yang dimaksud adalah ekspresi yang tidak tergolong baru lagi. Sehingga, kata ekspresi budaya tradisional dalam tulisan ini dimaksudkan sebagai karya atau ekspresi yang berasal dari kegiatan (intelektual) manusia dan telah berlangsung lama.

Untuk melihat bagaimana hubungan antara ekspresi budaya tradisional dengan karya di bidang HKI, yang sejak awal telah dikatakan adanya keterkaitan dan keterikatan pada keduanya, maka perlu diperjelas lagi mengenai kategorisasi karya-karya HKI. Sebagaimana telah diuraikan sebelumnya, karya yang termasuk sebagai karya HKI itu mesti (1) dituangkan ke dalam suatu karya (ekspresi kreatif), dan (2) mengandung kebaruan (dalam hak cipta disebut orisinil). Dari pemahaman mengenai kriteria karya HKI ini diharapkan akan diketahui apakah ekspresi budaya tradisional termasuk ke dalam HKI atau tidak (?); dan kalaupun tidak, lalu bagaimana hubungan di antara keduanya (?)

Pertama, berkaitan dengan ekspresi kreatif, maka karya HKI terbagi ke dalam hak cipta, paten, merek, desain industri, DTLST, indikasi geografis, rahasia dagang, dan PVT. Ekspresi tersebut berwujud dalam bentuk buku dan karya-karya sastra, kesenian semisal lagu, ceramah/ pidato, invensi, kreasi tampilan suatu produk, dan tanda pada suatu produk (perdagangan) dan jasa.

Kedua, mengenai syarat kebaruan, yang sebenarnya terdapat perbedaan di antara masing-masing bidang HKI, namun secara umum tetap sama-sama ditujukan bagi keaslian atau keberbedaan suatu karya dengan karya yang telah ada sebelumnya. Di sini, perbedaan itu terletak pada bentuk kebaruannya, apakah terkait dengan isi dari suatu karya, bentuk tampilan, atau malah fungsinya. Pada hak cipta, meski tidak ada syarat kebaruan, namun syarat orisinalitas berupa keaslian karya tersebut dari penciptanya, sebenarnya hanyalah varian dari syarat kebaruan yang ditujukan kepada isi suatu karya. Pada paten, rahasia dagang, dan PVT, kebaruan terletak pada isi dan fungsinya, pada desain industri terletak pada bentuknya, sedangkan pada merek dan indikasi geografis terletak pada isi dan bentuknya.

suatu kompleks aktivitas kelakuan berpola manusia dan benda-benda hasil karya manusia. Meski pada wujud kebudayaan yang demikian ini juga pasti terdapat nilai-nilai atau gagasan-gagasan dari masyarakatnya, tetapi untuk kepentingan metodologis maka di antara hasil dan nilai itu akan dipisahkan dalam tulisan ini. Dan biasanya, terutama dalam kajian sosiologi budaya, hasil (produk) kebudayaan ini dikenal pula sebagai bentuk simbolik dari budaya (Kuntowijoyo. 2006. Budaya dan Masyarakat. [Edisi paripurna]. Yogyakarta: Tiara Wacana. Hlm. 6). 
Kedua hal di atas, yaitu ekspresi kreatif dan kebaruan, merupakan tolok ukur paling mendasar dalam menentukan termasuk dan tidaknya suatu karya sebagai karya HKI. Jika keduanya kemudian digunakan untuk melihat apakah ekspresi budaya tradisional termasuk sebagai bagian dari karya HKI atau tidak, maka dapat dikatakan, pertama, syarat HKI berkaitan dengan adanya ekspresi kreatif sebenarnya sangat mungkin untuk terpenuhi pada ekspresi budaya tradisional. Rumitnya gerakan dalam tari piring, beragamnya kreasi dalam seni ukir Jepara, menariknya cerita Malin Kundang, serta dapat digunakannya tanaman temu lawak untuk mengobati berbagai macam penyakit, misalnya, tampaknya sulit untuk mengatakan tidak adanya kreatifitas intelektual di sana. Ekspresiekspresi tradisional itu tidaklah lahir begitu saja. Ia, jika memang harus dikuantifikasi sebagaimana halnya dalam hitung-hitungan karya HKI, juga bermula dari adanya kegiatan olah pikir manusia yang kreatif, dan secara material tentu saja mengorbankan waktu, biaya, dan sebagainya.

Akan tetapi, sekaligus sebagai pernyataan kedua, tampaknya mustahil pula jika harus menggolongkan ekspresi budaya tradisional itu ke dalam karya yang baru sehingga dapat disebut karya HKI. Bahwa gerakan tari piring semelok itu, cerita Malin Kundang dapat 'menghipnotis' masyarakat untuk tidak durhaka kepada orang tuanya, ukiran Jepara yang penuh nilai estetika, dan digunakannya tanaman temu lawak dalam berbagai obatobatan tradisional, sepertinya sudah diketahui oleh banyak orang sejak puluhan atau bahkan mungkin ratusan tahun yang lalu. Karena itu, karyakarya semacam cerita Malin Kundang di atas tidaklah mengandung kebaruan lagi untuk masa sekarang, dan mengkategorikannya sebagai bagian dari karya di bidang HKI, jelas menjadi tidak tepat.

\section{Dialektika Dalam Perlindungan Hukum Ekspresi Kreatif}

Secara prinsipil memang terdapat perbedaan antara ekspresi kreatif pada budaya tradisional dengan ekspresi kreatif pada HKI, dikarenakan yang disebut pertama didasarkan pada ekspresi yang hidup dan berlangsung sejak lama di masyarakat, sementara yang disebut terakhir lebih mengedepankan kepemilikan individu dan adanya kebaruan. Namun demikian, jika mencermati bahwa di antara keduanya sama-sama berangkat dari adanya kreatifitas intelektual, serta adanya standar ganda yang diterapkan oleh sistem HKI terhadap yang lainnya, maka di antara keduanya jelas menyimpan hubungan yang sangat erat sekali. 
Hubungan di antara ekspresi budaya tradisional dan HKI tidaklah sekedar didasarkan pada alasan bahwa keduanya sama-sama bermula dari adanya kegiatan intelektual yang kreatif. Hubungan itu juga didasarkan oleh adanya perkembangan dan pengembangan salah satu dari bentuk ekspresi kreatif itu yang dalam praktiknya berakibat pada lahirnya bentuk kreatifitas yang lainnya lagi. Karena itulah, pada HKI dan ekspresi budaya tradisional itu sebenarnya terjalin hubungan ekspresi kreatif yang dialektis, termasuk dalam perlindungan hukumnya.

Penjelasan pernyataan di atas adalah sebagai berikut. Pada suatu proses pertumbuhan, definisi 'baru' biasanya muncul dikarenakan sebelumnya telah ada yang 'lama', dan begitu juga sebaliknya, sesuatu menjadi 'lama' disebabkan ada yang 'memperbarui' nya di kemudian hari. Bahkan, sesuatu yang disebut 'baru' ini pun pada masanya nanti akan menjadi 'lama' oleh sesuatu yang memperbaruinya lagi. Begitulah, proses saling memperbarui sesuatu akan selalu ada dalam kehidupan ini selama proses berpikir manusia juga masih tetap berjalan. Ini berarti dimensi waktulah yang menentukan baru dan lamanya sesuatu itu.

Tidaklah hanya dipengaruhi oleh dimensi waktu, status sesuatu sebagai 'baru' dan 'lama' juga dapat dipengaruhi dimensi ruang. Keberadaan masyarakat di ruang yang berbeda, terlebih dengan jarak yang sangat berjauhan, tentu sangat mempengaruhi masyarakat tersebut dalam menemui, memahami, dan menafsirkan sesuatu itu sebagai lama atau baru. Sehingga, meski dalam waktu yang bersamaan sesuatu menurut masyarakat di ruang A dianggap telah 'lama', namun sesuatu ini sangat berkemungkinan bagi masyarakat $\mathrm{M}^{10}$ masih merupakan sesuatu yang asing dan kehadirannya dengan demikian dianggap 'baru'. Sebut sajalah ukiran Jepara, bagi masyarakat Jepara dan sekitarnya tentu sudah terlalu biasa, tetapi bagi para pengunjung dan pembeli luar negeri yang mereka tidak pernah menemuinya, ukiran tersebut akan dikatakannya sebagai 'baru'.

Konsep baru dan lamanya suatu ekspresi kreatif manusia, juga tidak lepas dari dimensi waktu dan ruang di atas. Meski secara teks dikatakan bahwa konsep yang berlaku dalam sistem HKI hanya didasarkan pada dimensi waktu, tetapi hal ini tidaklah menjamin dimensi ruang juga

${ }^{10}$ Pengandaian masyarakat A dan M dimaksudkan sebagai masyarakat yang dimensi ruangnya berjauhan, sebagaimana jauhnya jarak antara A dan $\mathrm{M}$ dalam daftar alfabet. Jika dengan M saja pemaknaan lama dan barunya sesuatu sudah berbeda, tentu keberbedaan ini menjadi lebih terbuka bagi masyarakat yang ruangnya lebih berjauhan lagi, misalnya dengan $\mathrm{T}$ dan apalagi $\mathrm{Z}$. 
mempengaruhinya. Dalam beberapa kasus, dimensi ruang bahkan bukan lagi sekedar mempengaruhi tetapi sangat menentukan lama dan barunya sesuatu itu. ${ }^{11}$ Ketiadaan data-data dan bukti-bukti formal di ruang tertentu yang menunjukkan sesuatu itu sebagai lama, dalam perkembangannya berakibat pada barunya status sesuatu itu di ruang yang berbeda.

Tulisan ini tidak dimaksudkan untuk meragukan atau menggugat kemapanan sistem perlindungan HKI, karena bagaimanapun juga sistem HKI itu menyimpan tujuan yang mulia, yaitu melindungi penggunaan suatu karya yang telah dihasilkan dengan jerih payah. Keberadaan sistem HKI memungkinkan bagi terhindarinya penyalahgunaan dalam pemanfaatan suatu karya, dan juga mendorong dihasilkannya karya-karya kreatif berikutnya. Hanya saja, menurut hemat penulis, tentu menjadi tidak tepat jika hukum kemudian dikonsentrasikan untuk melindungi ekspresi HKI dan mengabaikan perlindungan ekspresi budaya tradisional. Hukum, dalam suatu dinamika yang dialektis, seharusnya tidak memusatkan perlindungan pada salah satu sudut saja dari ekspresi kreatif manusia, dalam hal ini pada karya HKI, tetapi juga hendaknya menjamin perlindungan ekspresi budaya tradisional.

Dalam kaitan ini, menurut Edy Sedyawati, kehidupan dengan kehangatan dan keikhlasan berbagi dalam karya cipta pada masyarakat tradisional sebaiknya tidak perlu diusik oleh isu hak cipta yang individual. Namun demikian, jangan sampai pula asas kebersamaan internal itu kemudian disalahgunakan oleh pihak-pihak di luar komuniti dan mengambil manfaat ekonomis darinya. ${ }^{12}$ Karena itulah, hukum diharapkan sebaiknya dapat menjamin terlindunginya berbagai macam ekspresi kreatif manusia itu, baik yang berupa HKI maupun ekspresi budaya tradisional.

\footnotetext{
${ }^{11}$ Sebagai contoh di sini dapat dikemukakan pada hasil studi Agus Sardjono. Studi Sardjono tentang obat-obatan tradisional menyebutkan banyak sekali obatobatan yang telah tradisional di suatu negara, yang umumnya negara berkembang, kemudian diakui sebagai obat-obatan baru oleh pihak-pihak di negara maju dan didaftarkan HKI-nya. Misalnya saja, pendaftaran HKI oleh perusahaan Amerika, W.R. Grace terhadap pengetahuan masyarakat tradisional India dalam penggunaan biji pohon Neem, dan juga klaim Beatric Foods, Lucky Biotech dan University of California atas pengetahuan masyarakat Afrika bagian tengah dan barat dalam penggunaan biji-bijian tanaman Katemfe. Keterangan lebih lanjut mengenai hal ini dapat dilihat dalam: Agus Sardjono. 2006. Hak Kekayaan Intelektual dan Pengetahuan Tradisional. Bandung: Alumni. Hlm. 38-44.

${ }^{12}$ Edy Sedyawati. 2005. "Masalah Berbagi dalam Ekspresi Budaya Tradisional," Media HKI, Vol. II/No. 2 April. Jakarta: Direktorat Jenderal HKI, Departemen Hukum dan HAM RI. Hlm. 11-13.
} 


\section{Upaya Melindungi Ekspresi Budaya Tradisional}

Pada bagian terdahulu telah disampaikan bahwa dalam suatu hubungan yang dialektis di antara HKI dan ekspresi budaya tradisional, hukum sebaiknya tidak memusatkan perhatian perlindungan pada salah satu saja dari kedua ekspresi kreatif ini. Hukum yang baik, yaitu hukum yang memberikan keadilan, seharusnya dapat melindungi kedua ekspresi kreatif dari kegiatan (olah pikir) manusia tersebut.

Di Indonesia, perlindungan atas kreatifitas intelektual sebenarnya diarahkan untuk mengakomodasi keduanya. Meski titel peraturan perundang-undangan yang digunakan berpegang pada $\mathrm{HKI}$, namun di antara materi yang dilindungi itu juga memuat keinginan dari pemerintah untuk melindungi ekspresi budaya tradisional. Rumusan UU Hak Cipta (UU No. 19 Tahun 2002) merupakan contoh terbaik dalam hal ini. Di dalam rumusan UU Hak Cipta disebutkan, suatu ciptaan itu tidak saja terdiri dari karya-karya orisinal di bidang ilmu pengetahuan, seni, dan sastra, tetapi juga karya-karya peninggalan prasejarah, sejarah, dan budaya nasional (Pasal 10 Ayat 1), serta juga foklore dan hasil kebudayaan rakyat yang mejadi milik bersama, seperti cerita, hikayat, dongeng, legenda, babad, lagu, kerajinan tangan, koreografi, tarian, kaligrafi, dan karya seni lainnya (Pasal 10 Ayat 2). Terhadap karya-karya peninggalan dan ekspresi budaya tradisional itu, negara bertindak sebagai pemegang hak ciptanya, termasuk di sini memberikan izin ketika orang yang bukan warga negara Indonesia akan mengumumkan atau memperbanyaknya (Pasal 10 Ayat 3).

Hal itu berarti, perlindungan ekspresi budaya tradisional secara tekstual sebenarnya telah dimungkinkan, meski itupun baru pada bidang kesenian dan bahkan aturan pelaksananya juga belum terbit hingga sekarang. Namun demikian, dengan kenyataan masih terjadinya penyalahgunaan dalam pemanfaatan ekspresi budaya tradisional serta proses penyanggahan dan penyelesaiannya yang tidak gampang, tampaknya menjadi indikasi betapa perlindungan atas ekspresi budaya tradisional di Indonesia sesungguhnya belum berjalan dengan baik. Karena itu, perlu dibahas bagaimana seharusnya perlindungan atas ekspresi budaya tradisional itu diberikan sehingga dapat mengejar kemapanan sistem perlindungan HKI.

Menurut penulis, dalam rangka melindungi ekspresi budaya tradisional itu, ada dua hal yang setidaknya perlu segara dilakukan sekarang ini, yaitu inventarisasi dan dokumentasi ekspresi budaya tradisional. Pertama, mengenai 
inventarisasi ekspresi budaya tradisional, hal ini penting untuk mengetahui ekspresi budaya apa dan mana saja yang sebenarnya asli dari Indonesia, dan mana pula yang sekedar modifikasi atau bahkan tiruan dari kebudayaan bangsa asing. Sebagai wilayah yang lama dikuasai oleh kolonial, serta arus masuk globalisasi yang semakin deras, jelas menjadikan inventarisasi atas ekspresi budaya tradisional asli masyarakat Indonesia tidak mudah dilakukan.

Contoh berikut ini yang diambil dari tulisan Ajip Rosidi ${ }^{13}$ menggambarkan betapa inventarisasi ekspresi budaya tradisional itu tidak mudah. Selama ini, cerita Si Bachil dan Si Kabayan Jadi Dukun sudah akrab dipahami sebagai cerita yang hidup dan berasal dari Indonesia, terutama daerah Jawa Barat. Namun sebenarnya, kedua karya tersebut adalah karya Moliere yang berjudul L'Avare dan Le Medicin Malgre Lui, yang kemudian dialihbahasakan ke dalam bahasa Indonesia oleh Noer St. Iskandar (untuk karya L'Avare, dan di Indonesia dikenal Si Bachil) dan (satu karya lagi oleh) Moh. Ambri. Alih bahasa yang tidak menyebutkan judul asli serta nama penulisnya inilah yang kemudian membentuk opini masyarakat bahwa keduanya merupakan cerita yang berasal dari Indonesia.

Adanya kerumitan tersebut mengharuskan kegiatan inventarisasi ekspresi budaya tradisional untuk melibatkan berbagai pihak yang berkepentingan dan terlibat langsung, semisal masyarakat yang menjadi adresat ekspresi budaya tradisional itu, budayawan, dan pakar yang ahli di bidangnya. Jika partisispasi masyarakat--sebagai adresat--diperlukan untuk menginformasikan isi dan bentuk dari suatu ekspresi budaya tradisional, maka partisipasi budayawan dan pakar ahli di bidangnya dimaksudkan untuk menilai keaslian dan ciri khas yang melekat pada ekspresi budaya yang dimaksud.

Kedua, perlu diselenggarakannya dokumentasi atas ekspresi budaya tradisional yang telah diinventarisir itu. Kalau inventarisasi dimaksudkan untuk mengidentifikasi keaslian dan ciri khas dari ekspresi budaya tradisional, maka dokumentasi diperlukan untuk menampilkan bukti dokumen bahwa atas ekspresi budaya tradisional tertentu yang sudah teridentifikasi itu sebagai milik bangsa Indonesia.

Pelaksanaan dokumentasi ini, mutatis mutandis pada inventarisasinya, tentu saja perlu memanfaatkan berbagai hasil dokumentasi yang tersedia

${ }^{13}$ Ajip Rosidi. "Kesadaran akan Hak Cipta", Kata Pengantar dalam Tamotsu Hozumi. 2006. ASIAN Copyright Handbook (terj. Masri Maris). Jakarta: ACCU \& Ikapi. Hlm. xvi. 
di masyarakat sebagai salah satu sumbernya. Hal ini dikarenakan tentu tidak sedikit budayawan dan seniman yang sampai saat ini secara konsisten meneliti dan membukukan berbagai budaya yang ada di tanah air. Karena itulah, ke depan menjadi perlu diselenggarakan inventarisasi dan dokumentasi yang sifatnya terencana serta melibatkan berbagai pihak yang berkepentingan dan terlibat langsung atas suatu ekspresi budaya tradisional. Rencana pemerintah propinsi Sumatera Selatan yang hendak membangun museum tekstil di palembang yang berisi motif-motif tenun songket tradisional yang ada di sana, dapat dibaca sebagai salah satu upaya terencana tersebut. ${ }^{14}$

Dua upaya tersebut, yaitu inventarisasi dan dokumentasi, tampaknya menjadi kegiatan yang paling mendesak untuk segera diselenggarakan dalam melindungi ekspresi budaya tradisional sekarang ini. Terselenggaranya inventarisasi dan dokumentasi diharapkan semakin memperjelas identitas keberadaan suatu ekspresi budaya tradisional yang ada dan hidup di Indonesia, sekaligus juga menjamin keberlanjutannya. Penyederhanaan upaya dalam dua hal ini bukan dimaksudkan untuk mengabaikan cara-cara lainnya yang selama ini juga sering mengemuka, seperti pembaharuan UU dan penyiapan sistem bagi hasil (benefit sharing) dalam pemanfaatan ekspresi budaya tradisional. Namun demikian harus pula dikatakan di sini bahwa terselenggaranya cara-cara lain itu pun tetap memerlukan inventarisasi dan dokumentasi. Karena itu, kiranya dapatlah dikatakan jika keduanya merupakan kegiatan yang paling mendesak dilakukan saat ini dalam upaya melindungi ekspresi budaya tradisional yang hidup di masyarakat.

\section{Penutup}

Berdasarkan uraian di atas dapat disimpulkan, bahwa ekspresi pada HKI dan eskpresi budaya tradisional itu pada dasarnya memang berbeda. Jika keduanya masih sangat mungkin bertemu pada adanya kesamaan ekspresi kreatif, tetapi keduanya berbeda dalam hal yang satu lebih mengedepankan kebaruan dan satunya lagi tidak. Meski demikian, adanya perbedaan ini tidaklah menjadikan keduanya tidak memiliki keterkaitan dan keterikatan. Terjadinya penyalahgunaan dalam pemanfaatan berbagai ekspresi budaya tradisional selama ini, terlebih yang dilakukan dengan

\footnotetext{
${ }^{14}$ Kompas. "Motif Songket Palembang Dipatenkan", 22 April 2006.
} 
menggunakan instrumen hukum HKI, menunjukkan adanya kedekatan hubungan relasional di antara HKI dan ekspresi budaya tradisional itu. Hubungan pada keduanya, dengan demikian dapat disebut sebagai sebuah dialektika dalam perlindungan hukum atas ekspresi kreatif manusia.

Sebagai sebuah dilaketika dari perlindungan ekspresi kreatif manusia, maka tentu menjadi sangat tidak tepat jika kemudian perlindungan hukum hanya diarahkan kepada salah satu saja dari ekspresi kreatif tersebut, dalam hal ini ekspresi kreatif yang baru, dan mengabaikan yang satunya lagi. Perlindungan ekspresi kreatif, dengan demikian sebaiknya juga mulai ditujukan kepada ekspresi budaya tradisional, sehingga mampu mengejar kemapanan sistem perlindungan HKI.

Upaya mendesak yang tampaknya perlu segera dilakukan dalam melindungi ekspresi budaya tradisional itu sekarang ini adalah menyelenggarakan inventarisasi dan dokumentasi atas ekspresi budaya tradisional yang ada dan hidup di Indonesia. Terselenggaranya inventarisasi dan dokumentasi diharapkan dapat memperjelas identitas keberadaan suatu ekspresi budaya tradisional, sekaligus juga berguna dalam mempertahankan klaim kepemilikannya dan menjaga kelestariannya.

\section{Daftar Pustaka}

Hozumi, Tamotsu, ASIAN Copyright Handbook, Jakarta, ACCU dan Ikapi, 2006.

Kesowo, Bambang, “UU Paten; Latar Belakang dan Prinsip-Prinsip Pokok", dalam Paten, Pemahaman dan Pelaksanaan. Tanpa kota: Pusat Pengkajian Hukum, 1993.

Koentjaraningrat, Kebudayaan, Mentalitas dan Pembangunan, (Cetakan keduapuluh satu), Jakarta, Penerbit PT. Gramedia Pustaka Utama,2004.

Kuntowijoyo,Budaya dan Masyarakat, (Edisi paripurna), Yogyakarta: Tiara Wacana, 2006.

Peursen, C. A. van, Strategi Kebudayaan, (Edisi kedua), Yogyakarta, Penerbit Kanisius,1988.

Purba, A. Zen Umar, “TRIPs dan Negara-negara Berkembang," Jurnal Hukum Internasional, Vol. 1 No. 2 Januari, Jakarta, Lembaga Pengkajian Hukum Internasional FH UI, 2004.

Rosidi, Ajip, "Kesadaran akan Hak Cipta", pengantar dalam Tamotsu Hozumi, ASIAN Copyright Handbook, Jakarta, ACCU \& Ikapi,2006. 
372 JURNAL HUKUM NO. 3 VOL.14 JULI 2007 : 359 - 372

Sardjono, Agus, Hak Kekayaan Intelektual dan Pengetahuan Tradisional, Bandung, Alumni, 2006.

Sedyawati, Edy, "Masalah Berbagi dalam Ekspresi Budaya Tradisional," Media HKI, Vol. II/No. 2 April, Jakarta, Direktorat Jenderal HKI, Departemen Hukum dan HAM RI, 2005.

Sherwood, Robert M, Intellectual Property and Economic Development, Virginia, Alexandria, 1990.

Sobary, Mohamad, "Tragedi Si Anak Durhaka", Kompas, 28 November, 2007.

Kompas. "Motif Songket Palembang Dipatenkan," 22 April 2006.

Koran Tempo. "Kasus Klaim Reog, Ponorogo Tempuh Jalur Hukum”, 23 November 2007.

Metro TV. "Metro Realita", 19 Maret 2008. 